\title{
Une lecture de vacances venue tout droit du Far West: Bleed, Blister, and Purge
}

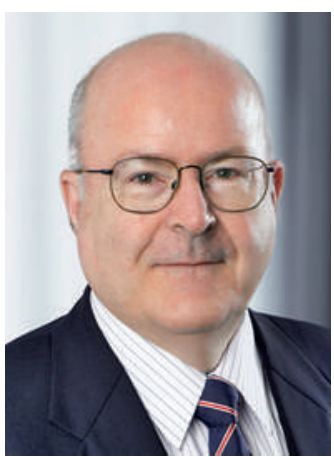

Werner Bauer
L'été qui avait fait apparaître quelques merveilleuses taches blanches dans nos agendas touche hélas déjà à sa fin. Les personnes qui en avaient profité pour voyager vivent désormais sur leurs souvenirs. Personnellement, j'aime voyager - mais j'ai sans cesse le même problème: j'emporte trop de livres, m'imaginant que j'aurai en route assez de temps pour me plonger à fond dans la lecture. De plus, l'étranger est émaillé de librairies coupables de ce que, lors du vol de retour, ma valise se voit régulièrement ornée d'un autocollant heavy.

J'ai découvert en Alaska un de ces livres, dont le titre est Bleed, Blister, and Purge. A History of Medicine on the American Frontier [1]. Racontée de façon vivante, l'histoire des médecins des territoires pionniers des USA impressionne, et cette lecture relativise une partie des soupirs poussés par les commentateurs actuels du système de santé.

Voici un extrait du chapitre House Calls on the Great Plains:

«A house call could last for hours, even days. Good doctors spent a lot of time at the bedside. Since no specific treatments were known for most ailments, a comforting presence was about all a physician could offer. The doctor's saddlebag served as a mobile clinic. It is remarkable how much the doctor's bag contained. Urling Coe, doctor in Bend, Oregon, carried a little leather case containing scalpels, artery forceps, needles, and some sutures.

In five canvas bags were bandages, splints, antiseptics, soap, basins, sterile towels and dressing, surgical instruments, and different drugs.

A good practitioner recognized the therapeutic value of touch. The laying on of hands> was once an important tool for the family doctor, but it seems to be losing favour with modern physicians. The warm immediacy of the human touch says, <Trust me; we're in this together, and I'm going to get you well.»»

Souhaitons que laying on of hands ne perde jamais la favour des médecins.

Voici une citation sur la distribution directe de médicaments: "Doctors on the frontier were expected to have a cure for everything from cancer to worms: Once the physician arrived at a diagnosis, he prepared a prescription. Although a few tablets were available as early as 1872, most medicines were powders contained in vials and painstakingly compounded at the bedside. Using the tip of a pocket knife, the doctor would select from several vials the proportions he needed. He blended the powders and folded each dose into a square of newspaper, so the medicine could be easily transferred to a teaspoon or a glass of water.»

Tandis que cette description emplit probablement d'horreur les collaborateurs de Swissmedic, les plus anciens parmi les lecteurs se souviennent de l'époque où, avec un regard empreint d'encouragement thérapeutique, le médecin mettait dans la main du patient une pochette de papier contenant une poudre.

Certains problèmes ne sont heureusement plus d'actualité, par exemple l'extraction de flèches d'Indiens, qui restaient souvent plantées dans le bras que la victime avait levé dans un réflexe de protection. Il n'était pas bon d'arracher soi-même immédiatement la flèche: "Arrowheads were loosely attached to the shaft, using animal materials such as tendon tissue or an organic glue. When this material became wet from the victim's blood, the connection was weakened. With such an insecure bond, the arrowhead usually stayed in when the shaft was pulled out, becoming a source of potential infection. Without the shaft as a guide, it was often hard for a surgeon to find and remove the arrowhead. Soldiers were warned not to pull out arrows, but most did anyway.»

L'auteur évoque également les rares thérapies disponibles qui étaient réellement efficaces: «From the 1790 s to about the middle of the 1800s was essentially the age of heroic medicine. There was only one disease, called 'morbid excitement induced by capillary tension'. This disease had a sole remedy: bloodletting and the purging of the stomach and bowels.»

Le fait que tout au long de l'histoire de la médecine des mesures curatives, loin d'apporter l'aide escomptée, ont hélas au contraire entraîné par exemple la mort, due à l'usage de saignées et de ventouses, de George Washington qui souffrait d'un abcès tonsillaire, amène l'auteur à faire une citation finale sans doute toujours justifiée aujourd'hui - et pas uniquement dans le domaine médical: «Wouldn't it be great if science textbooks spent some time on erroneous past understanding that everybody believed, that the church and the state and the scientists and the schools all thought, and turned out to be completely wrong. Isn't that a very useful lesson?»

Oui, ce serait là indubitablement une leçon fort utile.

Werner Bauer* 